\title{
Financial and Growth Analysis: A Comparative Study of Economic Sectors of Pakistan
}

\author{
Dr. Jamil Anwar \\ Assistant Professor, Department of Management Sciences \\ COMSATS University, Abbottabad Campus \\ jamilanwar@cuiatd.edu.pk
}

Dr. Said Shah

Assistant Professor and Head, Department of Management Science

University of Swabi, KP

saidshah@uoswabi.edu.pk

\begin{abstract}
Most studies on financial analysis take firms as the unit of analysis and then compare the performance across the sectors. Taking economic group of an economy the unit of analysis, this research presents a comparative financial ratios analysis of economic groups composed of listed companies at Pakistan Stock Exchange (PSE). The analysis is based on the profitability, liquidity, efficiency, leverage, growth and trends over a period of time using 5 years data of non-financial listed companies. The results show that profitability ratios for Food, Chemicals, Cement, Motor vehicle, Fuel \& energy sector and Coke sectors are performing above the overall average R.O.A and NPM while the Textile, Sugar, Manufacturing, Minerals, Information and Communication, Electric machinery and Other Services economic groups are performing below the overall averages. Sales growth of Manufacturing, Mineral product, Cement and Other services activities economic groups are performing above 50\%. While Textile, Sugar, Food, Chemicals products, Motor vehicle, Fuel \& energy, Info. \& transport services, Coke and refined pet., Paper products and Electric machinery economic groups are performing below 50\%. Sugar economic group has liquidity and total asset turnover ratio above overall average but the profitability of this economic group is below overall average. It means that the economic group is not properly utilizing its liquidity for generation of profits. Similarly, Textile sector has profitability, efficiency and liquidity below the overall average of economic groups.
\end{abstract}

Key Words: Financial Ratios; Financial Analysis; Trend Analysis; Growth Analysis

\section{Introduction}

Financial statement analysis (FSA) is the process of evaluating and reviewing financial statements (such as income statement or balance sheet) of the companies, it helps to gain an understanding for the financial health and performance of the company and also helps to more effective decision making. Financial statement analysis is very useful for investors, managers, shareholders, and other having stake in the firm. FSA is the process that helps the firm to assess its financial position by analyzing its profitability, stability and viability. The purpose of financial statement analysis is to find out the major shifts in volume, amount and in financial trends and then to investigate why these changes occur to draw a logical conclusion about the performance. Financial analysis also enables to compare the performance of any firm or entity with its competitors.

The performance of economic groups (industries) play vital role in the overall economic and financial development of a country. Financial position of the company or a group of companies or an industry is assessed by considering descriptive and analytical measures of financial position and performance. Descriptive measures include total volume average \& variation about total assets, current assets, current liabilities, shareholders equity, total 
revenues, total expenses and net income etc. While analytical measures analyze the efficiency, liquidity, solvency and profitability of the organization. This also includes trend and growth analysis.

Generally individual firms or group of firms having similar characteristics (such as strategy, size etc.) are taken as a unit of analysis when financial analysis of an industry or a group of industries is done. There are very few studies that take industry (economic group) as a unit of analysis. This study fills this gap and takes economic group (Industry) as a unit of analysis and compares the efficiency, liquidity, leverage, and profitability of the economic groups in Pakistan. The objectives of the study are:

- To know the comparative position of economic groups in terms of liquidity, efficiency, leverage and profitability of different economic groups (industries) in Pakistan

- To know the comparative trends of selected financial indicators of economic sectors in Pakistan

- To compare the growth of selected financial indicators of economic sectors in Pakistan

To achieve these objectives, five years data of fourteen economic groups along with consolidated position of Overall, Public and Private sector is taken from State Bank of Pakistan (SBP) publication "Financial Statements Analysis Of Companies (Non-Financial)" Listed at Pakistan Stock Exchange (PSE). The techniques used for analysis include financial ratios to measure profitability, efficiency, leverage and liquidity of the sectors. Trend and growth analysis is also done for selected measures.

\section{Literature Review}

The Analysis of Financial data employs various techniques to emphasize the comparative and relative importance of the firm. These techniques include ratio analysis, common-size analysis, review of descriptive material, and comparison of results. One of the primary objectives of the financial analysis is the identification of major changes (turning points) in trends, amounts, and relationships and investigation of the reasons underlying those changes (Gibson, 2014).

Financial statement analysis involves two steps, 1) comparing the performance of firm with the performance of any other firm and 2) trend evaluation in the financial statement of the firms over a certain period of time. Financial analysis is used by different people like managers use to identify the critical situations; lenders use the financial statement analysis to identify the firm's creditworthiness; and stock holders use to predict the dividends, free cash flow and future earnings (Ehrhardt \& Brigham, 2017).

Several studies have been conducted to analyze the performance of firms. Many studies mainly focus on using the financial ratios while some studies used the nonfinancial ratios to analyze the firm performance (Bashir \& Akram, 2013). The financial status of the company is very important because when the firm is financially more stable then it guarantees to increase the firm value and also ensures the ability of firm to generate returns for investors (Tahir, 2012). While evaluating the financial position of company, operating results and comparing with the previous years or other company's ratios give useful guidance (Tamimi, 2012).

Financial ratios are generally used for financial analysis to connect the various predictions from the financial statements. Financial ratios are used so that the financial condition of the firm can be measured (Kirkpatrick, 2007). Financial ratios represent the following financial characteristics: Liquidity; Activity; Solvency; Profitability; Repayment Capacity; and Financial Efficiency (Ahrendsen, 2012; Ramathan, 2007). Ratios can be used to show the standing of any organization or industry while using them as a tool in the financial analysis. 
But financial analysis is more than interpretation of some ratios (Leslie Rogers, 1997). Some of the commonly used ratios are defined below:

- The liquidity ratios enable the firm to determine its ability to implement the process of production and also fulfill the financial obligations at the given time period.

- The activity or efficiency ratio determines the company's ability to perform daily activities.

- The profitability ratio helps out the company to determine the ability of gaining profits from the decisions and policies that have been taken.

- The solvency or leverage ratio measures that how much company's assets are financed by debt

Ratios can be used to do trend analysis. It can be done yearly, by extracting the data from the annual statements of the organizations, giving it, a meaningful interpretation based on respective ratios and comparing year-to-year data to see the trend. Three to five years are best for trend analysis. Trend analysis can also be done through cross sectional analysis; comparison is made between two or more companies of same business line to see the trends. Another way to do cross sectional trend analysis is by comparing the company's ratios to the sectors average provided by the statistical services and trade association (Ezzamel, MarMolinero and Beecher, 1987).

Different researchers have divided the ratios into categories. For example, Courtis, 1987 categorizes the ratios as: profitability ratios, short-term solvency ratios (liquidity ratios) and long-term solvency ratios (capital structure ratios). Owens and Epstein (1995) categorized the financial ratios in four basic types: liquidity ratios, activity ratios, debt ratios and profitability ratios. The ratios such as liquidity, activity and debt can be used to measure risk while profitability can be used to measure return. Perttunen and Martikainen (1970) use a set of four types of ratios to analyze the financial statements. These ratios are: profitability ratios, liquidity ratios, efficiency ratios (Asset management) and leverage ratios (Debt management). Where profitability ratios include, return on asset, return on equity and net profit margin. Liquidity ratio includes, current ratio, quick ratio. Leverage ratio includes, debt to equity ratio and debt to F.A. and efficiency ratio includes, total asset turnover, inventory turnover and trend and growth analysis is also done for some selected financial indicators such as total assets, current assets, stakeholders' equity and sales.

Some precautions need to be made while doing ratio analysis. First, is to make sure to use more than one ratio, one ratio can be misleading and do not have sufficient information. So, it is advisable to use two or more ratios to get better results. Second, is to use the audited financial statements. Because un-audited financial statements are not that trustworthy and can be have some misleading figures. Third, is to use other ratios for comparison designed in the same way, with same formulas and same procedures. So that the comparison is good enough to be used for any further research or can be used as a benchmark in the future (Whitis, Keith, 1993). While doing financial analysis first task is to select and calculate all the relevant ratios but crucial step is to interpret them relative to company's last year figures, known as the bench-marking or the cross-sectional analysis, or it can be done with ratios of competitor or the group of competitors (Gitman, 1997).

Firm's evaluation can be done through time -series. For this purpose old year ratios are used to compare it with latest ratios to see the trend over the time. This is done by the help of ratio analysis on two different time horizons: past analysis and present analysis (Gitman, 1997).

Based on the review of literature above, this study applied four types of financial ratios to measure the comparative liquidity, efficiency, leverage and the profitability of the economic sectors of Pakistan. The trend analysis is also done to see the performance over the time. 


\section{Research Methodology}

This section explains the data set used for conducting this study. The detail of the sectors, definition of variables, ratios and their implication is also presented here.

\section{Data Collection}

Five years (2011-2015) data of fourteen economic groups is taken from State Bank of Pakistan (SBP) publication "Financial Statements Analysis Of Companies (Non-Financial)" Listed at Pakistan Stock Exchange. The sector wise distribution of companies is presented in Table 1.

\section{Financial Analysis}

For analyses, five years data was averaged to find out the ratios (profitability ratio, efficiency ratio, leverage ratio and liquidity ratio) and trend analysis for all economic groups (industries). The measures are described below:

\section{Profitability Ratios}

These ratios measure the profitability of the firm. Profitability ratios mainly focuses on defining that how a firm can efficiently earn profits from their operations. This study used the following two measures of profitability.

- ROA

It tells how much a firm is profitable in relation with its total assets and is calculated as;

ROA=Net Profits/Total Assets.

It measures how efficiently a firm utilizes its assets to convert them into profits.

\section{- NPM}

This ratio compares the net profits with the revenues of firm and is calculated as;

NPM=Net Profit/Revenue.

This ratio helps in tracking the decrease and increase in the profits over a time.

Table 1: Sector-wise Distribution of the Firms

\begin{tabular}{|c|c|c|}
\hline Economic Sectors & No. of firms & $\begin{array}{l}\text { Contribution } \\
\text { in } \%\end{array}$ \\
\hline Textile & 147 & 38.2 \\
\hline Sugar & 31 & 8.1 \\
\hline Food & 15 & 3.9 \\
\hline Chemicals, Chemical Products \& Pharmaceuticals & 45 & 11.7 \\
\hline Manufacturing & 32 & 8.3 \\
\hline Mineral Products & 8 & 2 \\
\hline Cement & 19 & 4.9 \\
\hline Motor Vehicles, Trailers and Auto parts & 18 & 4.6 \\
\hline Fuel \& Energy & 22 & 5.7 \\
\hline Information, Comm. And Transport Services & 11 & 2.8 \\
\hline Coke \& Refined Petroleum Products & 10 & 2.6 \\
\hline Paper, Paperboard and Products & 8 & 2 \\
\hline Electrical Machinery and Apparatus & 7 & 1.8 \\
\hline Other Services Activities & 11 & 2.8 \\
\hline Total & 384 & 100 \\
\hline
\end{tabular}

\section{Efficiency Ratios}

- The other name of this ratio is activity ratio. Efficiency ratio is basically used to analyze that how a firm uses its liabilities and assets internally. With the help of this ratio firms calculate the turnover of receivables means in how much time firms collect cash from customers or in how much time firm convert the inventory into sales. This study uses total asset turnover (TAT) and inventory turnover (ITO) as the measure of efficiencies. These are explained below. 


\section{- Total Asset Turnover}

Total asset turnover ratio measures the sales value or revenue value with respect to the value of assets of firm. This ratio is also considered as sign of efficiency through which firm is using assets for generating the revenue and is calculated as;

Total Asset Turnover=Sales/Average total asset

Normally total asset turnover ratio is calculated over annually basis. Average total asset is calculated by the taking the average of assets that are held in the beginning of the year and at the end of the year.

\section{- Inventory Turnover}

Inventory turnover ratio shows that how many times a firm sold its inventory or replaced over a certain period of time and is calculated as;

Inventory Turnover $=$ Sales/Inventory

Inventory turnover ratio considered the purchase of stock by firm and then the sale of that stock. If the purchase is greater than that of sale then the firm need to speed up the sale. Otherwise they will incur the costs like holding and storage costs.

\section{Leverage Ratios}

Leverage ratio measures that how much debt is attained by the firm and how much is the ability of firm to pay these liabilities. Normally firms use the mix of debt and equity to finance their operation. The leverage ratio helps to know that the debt held by firm is either payable on due date. Too much debt is not good for the financial health of firm and its investors because high level of debt lead towards the bankruptcy. Leverage ratio is very helpful in indicating that how firm is acquiring assets and growing over a period of time. Debt to equity ratio and debt to total asset ratios used for this study are explained below:

\section{- Debt to Equity Ratio (DER)}

DER= Total liabilities/Shareholders equity

This ratio helps to calculate the financial leverage of firm. This ratio tells that how much debt a firm is using to finance their assets with respect to the shareholder's equity value. It can be expressed in numbers or either in percentages. Debt to equity ratio is also called the gearing ratio. High debt to equity ratio indicates that firm is using debts more as compared to equity. High level of debt usage leads towards the high-risk level.

\section{- Debt to Total Asset Ratio (DAR)}

\section{DAR=Total debt/Total asset}

It is the ratio which indicates the total debt with respect to the total asset. Higher debt to total asset ratio means that there is greater financial risk. Total debt includes the sum of short term and long-term debt and total assets includes the sum of current asset and non-current asset.

\section{Liquidity Ratio}

Liquidity ratio tells about the performance of a firm either the firm is able to pay its debt when it due. Liquidity ratio inform about the level of cash of a firm and also the ability of firm to pay its current obligations or liabilities. Current liabilities are considered in relation with liquid assets to confirm that firm is able to pay debts in short term. Liquidity ratio includes the current ratio and quick ratio. These are explained below:

\section{- Current Ratio (CR)}

$\mathbf{C R}=$ Current assets/Current liabilities

Current ratio is the type of liquidity ratio which indicates the information about the ability of firm to pay short term as well as long term financial obligations or debts. Current ratio considered the total current assets (liquid and illiquid assets) with respect to the total current liabilities. Current ratio can also be known as working capital ratio.

- Quick Ratio (QR)

$\mathbf{Q R}=($ Current assets - Inventories $) /$ Current liabilities 
Quick ratio measures the ability of firm to pay its short-term liabilities by considering its most liquid assets only. Quick ratio is more concerned about the current assets that's why inventories are excluded from current assets.

\section{Growth Analysis}

Growth analysis tells us the growth of companies over a certain period of time with respect to any previous year. It tells the changes in growth over time.

The formula of growth is as follows:

Growth $=($ Present year - Past year $) /$ Past year.

For this study, 2011 data is taken as base year and 2015 as current year data.

\section{Trend Analysis}

Trend analysis is basically considered as a technical analysis to forecast the expected future variability of items of financial statements based on the past data. Trend analysis prediction is based on the past data that give investors or traders the idea of what can happen in future.

This study has does the trend analysis of different sector on the basis of financial statements descriptive measures such as; Non-current Assets (N.C.A), Current Assets (C.A), Total Assets (T.A), Share Holders Equity (S.E), Non-current Liabilities (N.C.L), Sales, Gen. \& Adm. Expense and Profit After Tax etc.

\section{Results and Analysis}

This section presents the results and analysis of the study. The results for profitability, efficiency, leverage, liquidity, growth and trend analysis are presented in tabular as well as in graphical form.

\section{Profitability Analysis}

The results of profitability analysis are presented in Table 2 and Graph 1 . The top three indicators are in bold and bottom three are underlined for easy comparison. The results indicate that in term of N.P.M the performance of "Cement" sector is highest followed by "Fuel and Energy" and "Chemicals, Chemical Products and Pharmaceuticals" economic groups respectively. Whereas N.P.M was lowest for "Electric Machinery \& Apparatus", "Information Comm. \& Transport Services" and "Sugar" economic group respectively. Similarly, the results in term of ROA shows that "Food Products" economic group showed the highest performance followed by "Motor Vehicle" economic group while "Information Comm. \& Transport Services" and "Other Services Activities" economic group showed the lowest R.O.A.

Table 2: Profitability Analysis

\begin{tabular}{lcc}
\hline Sectors & $\begin{array}{c}\text { Net Profit } \\
\text { Margin (NPM) }\end{array}$ & $\begin{array}{c}\text { Return on Asset } \\
\text { (ROA) }\end{array}$ \\
\hline All Sector-overall & 7.45 & 8.31 \\
Private-overall & 6.18 & 6.53 \\
Public-overall & 10.22 & 13.38 \\
Textile & 2.85 & 3.02 \\
Sugar & $\underline{1.74}$ & 2.06 \\
Food Products & 9.43 & $\mathbf{1 8 . 7 3}$ \\
Chemicals, Chemical Products \& & $\mathbf{1 3 . 2 8}$ & $\mathbf{1 1 . 1 5}$ \\
Pharmaceuticals & & \\
Manufacturing & 5.07 & 5.41 \\
Mineral Products & 5 & 5 \\
Cement & $\mathbf{1 4 . 9 3}$ & 9.2 \\
Motor Vehicle, Trailers \& Auto parts & 6.29 & $\mathbf{1 3 . 4 5}$ \\
\hline
\end{tabular}




\begin{tabular}{lcc}
\hline Fuel \& Energy & $\mathbf{1 3 . 6 5}$ & 10.86 \\
Info. Comm. \& Transport Services & $\underline{1.71}$ & $\underline{0.3}$ \\
Coke and Refined Petroleum Products & 4.54 & 11.45 \\
Paper, Paperboard \& Products & 10 & 5.12 \\
Electric Machinery \& Apparatus & $\underline{1.37}$ & $\underline{1.16}$ \\
Other Services Activities & 2.96 & $\underline{1.42}$ \\
\hline
\end{tabular}

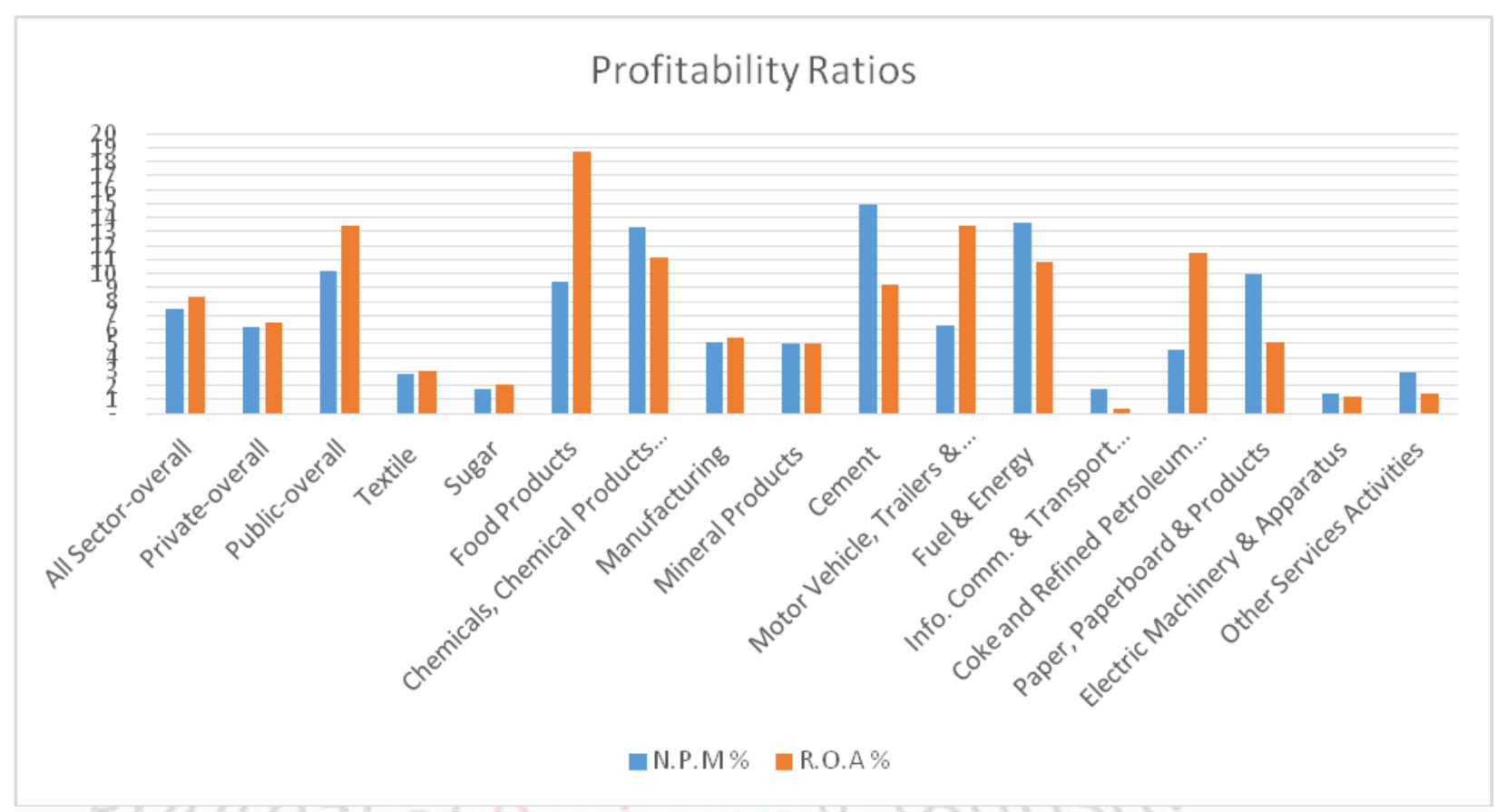

\section{Efficiency Analysis}

\section{Graph 1: Profitability Ratios}

The results for efficiency analysis are presented in Table 3. The results indicate that T.A turnover ratio for "Motor Vehicle, Trailers \& Autoparts" and "Coke and Refined Petroleum Products" are highest among all other economic groups. Whereas the "Textile", "Fuel \& Energy", "Chemicals, Chemical Products \& Pharma." and "Info. Comm. \& Transport Services" economic groups are indicating the lowest among all other groups. While the Inventory Turnover ratio indicates that "Fuel \& Energy" and "Info. Comm. \& Transport Services" are indicating the highest ratio among all other economic groups whereas "Manufacturing" and "Electric Machinery \& Apparatus" economic groups are indicating the lowest ratio as compared to others.

Table 3: Efficiency Ratio Analysis

\begin{tabular}{lcc}
\hline Sectors & $\begin{array}{c}\text { T.A Turnover } \\
\text { (TAT) }\end{array}$ & $\begin{array}{c}\text { Inventory } \\
\text { Turnover (IT) }\end{array}$ \\
\hline All Sector-overall & 1.06 & 10.52 \\
Private-overall & 1.02 & 8.77 \\
Public-overall & 1.17 & 19.68 \\
Textile & $\underline{0.98}$ & 4.93 \\
Sugar & 1.07 & 5.21 \\
Food Products & 1.81 & 8.2 \\
Chemicals, Chemical Products \& Pharma. & $\underline{0.8}$ & 9.55 \\
\hline
\end{tabular}




\begin{tabular}{lcc}
\hline Manufacturing & 1 & $\underline{3.64}$ \\
Mineral Products & 0.92 & 7.66 \\
Cement & 0.56 & 12.25 \\
Motor Vehicle, Trailers \& Autoparts & $\mathbf{2 . 0 4}$ & 6.99 \\
Fuel \& Energy & $\underline{0.74}$ & $\mathbf{9 1 . 4 1}$ \\
Info. Comm. \& Transport Services & $\underline{0.51}$ & $\mathbf{1 0 7 . 6 6}$ \\
Coke and Refined Petroleum Products & $\mathbf{2 . 3 7}$ & 13.21 \\
Paper, Paperboard \& Products & 0.5 & 5.35 \\
Electric Machinery \& Apparatus & $\underline{0.72}$ & $\underline{4.2}$ \\
Other Services Activities & $\underline{\underline{0.26}}$ & 5.85 \\
\hline
\end{tabular}

Leverage Analysis

The results (Table 4) show that the Debt to Total Asset Ratio of "Public-overall" and "Info. Comm. \& Transport Services" economic group is highest among all others whereas "Paper, Paperboard \& Products" and "Other Services Activities" economic groups are indicating the lowest ratio among all others. The Debt to Equity Ratio of "Public-overall" and "Sugar" economic group is indicating the highest ratio among the other economic groups while the "Paper, Paperboard \& Products" and "Other Services Activities" economic groups are indicating the lowest ratio as compared to other economic groups.

Table 4: Leverage Ratio Analysis

\begin{tabular}{lcc}
\hline Sectors & $\begin{array}{c}\text { Debt to Total } \\
\text { Asset Ratio }\end{array}$ & $\begin{array}{c}\text { Debt to Equity } \\
\text { Ratio }\end{array}$ \\
\hline All Sector-overall & 0.63 & 1.69 \\
Private-overall & 0.61 & 1.57 \\
Public-overall & $\mathbf{0 . 6 8}$ & $\mathbf{2 . 0 8}$ \\
Textile & 0.58 & 1.35 \\
Sugar & 0.71 & $\mathbf{2 . 4 7}$ \\
Food Products & 0.62 & 1.66 \\
Chemicals, Chemical Products \& & & \\
Pharmaceuticals & 0.62 & 1.6 \\
Manufacturing & 0.58 & 1.38 \\
Mineral Products & 0.6 & 1.5 \\
Cement & 0.45 & 0.93 \\
Motor Vehicle, Trailers \& Auto parts & 0.48 & 0.92 \\
Fuel \& Energy & 0.64 & 1.76 \\
Info. Comm. \& Transport Services & $\mathbf{0 . 9 3}$ & 13.65 \\
Coke and Refined Petroleum Products & 0.62 & 1.66 \\
Paper, Paperboard \& Products & $\underline{0.33}$ & $\underline{0.5}$ \\
Electric Machinery \& Apparatus & 0.61 & 1.58 \\
Other Services Activities & $\underline{0.3}$ & $\underline{0.43}$ \\
\hline
\end{tabular}

\section{Liquidity Analysis}

The results (Table 5) indicate that "Fuel \& Energy" and "Paper, Paperboard \& Products" economic groups have highest quick ratio among others. Whereas "Sugar" and "Info. Comm. \& Transport Services" has lowest quick ratio. While the current ratio of Motor Vehicle, Trailers \& Autoparts and Paper, Paperboard \& Products. Economic groups are highest. Whereas Sugar and Info. Comm. \& Transport Services economic group has lowest current ratio. 
Table 5: Liquidity Ratio Analysis

\begin{tabular}{lcc}
\hline Sectors & Quick Ratio & Current Ratio \\
\hline All Sector-overall & 0.82 & 1.05 \\
Private-overall & 0.76 & 1.04 \\
Public-overall & 0.96 & 1.09 \\
Textile & 0.55 & 1.04 \\
Sugar & $\underline{0.38}$ & $\underline{0.81}$ \\
Food Products & 0.56 & 1.09 \\
Chemicals, Chemical Products \& & & \\
Pharmaceuticals & 0.7 & 0.94 \\
Manufacturing & 0.46 & 1.1 \\
Mineral Products & 0.67 & 1.02 \\
Cement & 0.97 & 1.18 \\
Motor Vehicle, Trailers \& Autoparts & 1.01 & $\mathbf{1 . 6 5}$ \\
Fuel \& Energy & $\mathbf{1 . 1 6}$ & 1.18 \\
Info. Comm. \& Transport Services & $\underline{0.44}$ & $\underline{0.45}$ \\
Coke and Refined Petroleum Products & 0.89 & 1.22 \\
Paper, Paperboard \& Products & $\mathbf{1 . 1 2}$ & $\mathbf{1 . 6 7}$ \\
Electric Machinery \& Apparatus & 0.97 & 1.36 \\
Other Services Activities & 1.25 & 1.48 \\
\hline
\end{tabular}

\section{Growth Analysis}

Growth analysis shows the results of the growth of Total asset, Current asset, Total liabilities, Shareholders equity and Sales of the economic sector. The results are show in the table 6 . Growth analysis indicates that the "Public" and "Manufacturing" economic groups have highest Total Assets among all others. Whereas "Info. Comm. \& Transport Services" and "Electric Machinery \& Apparatus" have lowest Total Assets. Sales analysis indicates that the "Cement" and "Other Services Activities" economic groups have highest sales. Whereas the "Textile" and "Info. Comm. \& Transport Services" economic groups have lowest ratios.

Table 6: Growth Analysis (results are in percentage growth)

\begin{tabular}{lccccc}
\hline Sectors & $\begin{array}{c}\text { Total } \\
\text { Assets }\end{array}$ & $\begin{array}{c}\text { Current } \\
\text { Assets }\end{array}$ & $\begin{array}{c}\text { Total } \\
\text { Liabilities }\end{array}$ & $\begin{array}{c}\text { Shareholder } \\
\text { Equity }\end{array}$ & Sales \\
\hline All Sectors Overall & 41.67 & 36.13 & 26.26 & 64.36 & 23 \\
Private & 34.57 & 29.55 & 18.82 & 60.22 & 26 \\
Public & $\mathbf{6 3 . 4 6}$ & 51.97 & 48.2 & 79.11 & 16 \\
Textile & 26.67 & $\underline{4.62}$ & 9.23 & 53.99 & $\underline{-1}$ \\
Sugar & 37.35 & 16.02 & 27.4 & 57.4 & 8 \\
Food Products & 31.23 & 27.76 & 8.25 & 72.11 & 15 \\
Chemicals, Chemical Products \& Pharma. & 43.63 & 37.37 & 24.75 & 76.3 & 32 \\
Manufacturing & $\mathbf{6 2 . 0 3}$ & 47.2 & $\mathbf{6 7 . 4 8}$ & 69.63 & 67 \\
Mineral Products & 57.53 & 64.6 & $\mathbf{5 5 . 4}$ & 59.53 & 63 \\
Cement & 50 & $\mathbf{1 1 7}$ & 6.54 & $\mathbf{1 0 3 . 1 6}$ & $\mathbf{1 0 2}$ \\
Motor Vehicle, Trailers \& Autoparts & 42.93 & 49.65 & 2.09 & 60.13 & 47 \\
Fuel \& Energy & 60.58 & $\mathbf{6 3 . 6 1}$ & 38.74 & $\mathbf{9 3 . 7 6}$ & 28 \\
Info. Comm. \& Transport Services & $\underline{14.06}$ & 39.3 & 39.18 & $\underline{-94.65}$ & $\underline{4}$ \\
Coke and Refined Petroleum Products & 38.78 & 13.14 & 25.56 & 63.01 & 18 \\
Paper, Paperboard \& Products & 32.86 & $\underline{5.1}$ & 5.45 & 54.22 & 47 \\
\hline
\end{tabular}




\begin{tabular}{lccccc}
\hline Electric Machinery \& Apparatus & $\underline{6.15}$ & 9.88 & $\underline{-17}$ & 53.49 & 29 \\
Other Services Activities & 47.5 & 50.17 & 64.61 & $\underline{41.1}$ & $\mathbf{1 3 1}$ \\
\hline
\end{tabular}

\section{Trend Analysis}

The trend analysis showed the total change in Non-Current Assets (NCA), Current Assets (CA), Total Assets (TA), Shareholder Equity (SE), Non-Current Liabilities (NCL), Current Liabilities (CL), Sales, General administration and Other Exp (GAOE), and Profit After Tax (PAT). The results for overall data are presented in Graph 2. Similar trend was found for other groups. The differences are highlighted in finding section.

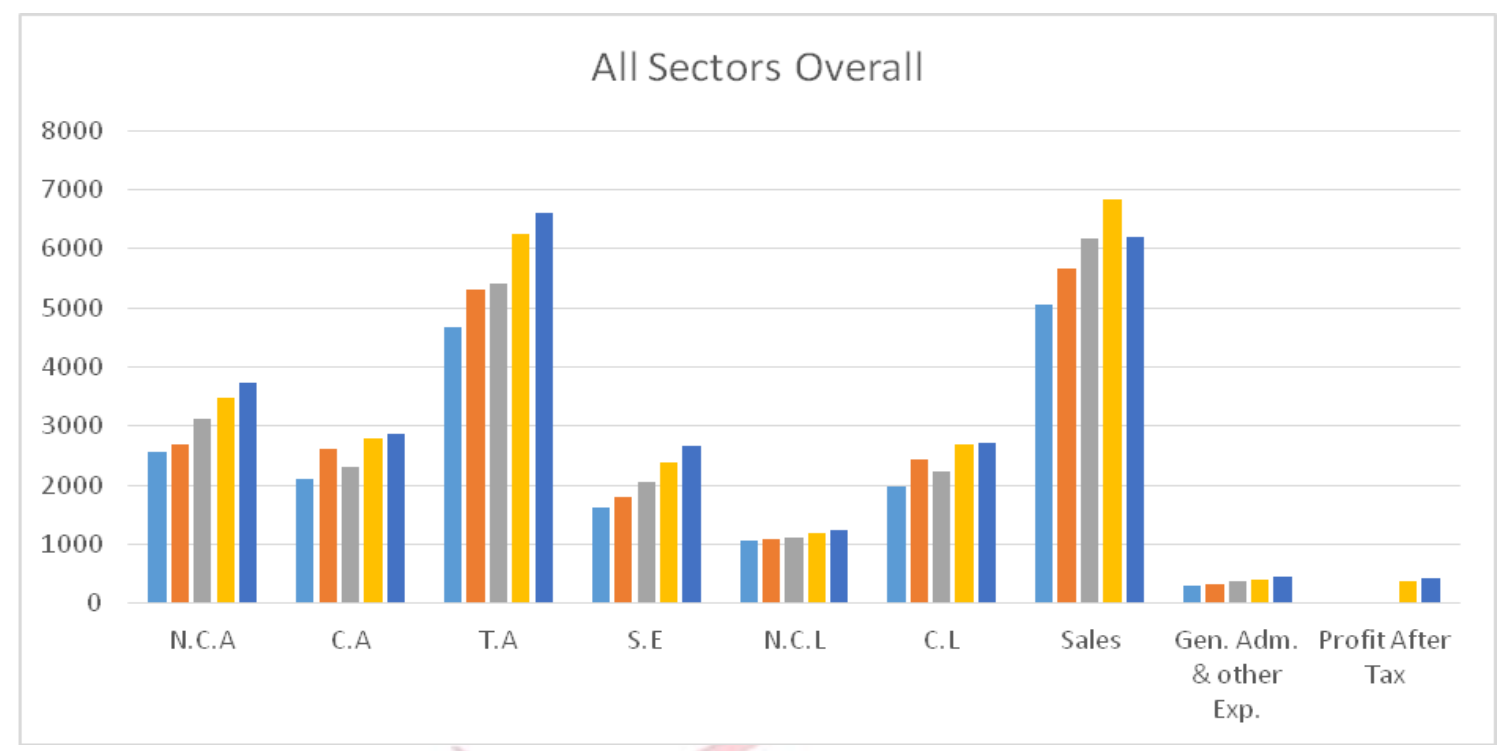

\section{Results and Discussion}

\section{Graph 2: All Sectors Overall Comparison}

The findings of the results based on ratio analysis (profitability ratios, efficiency ratios, leverage ratios and the liquidity ratios) and growth analysis are summarized in the Table $7 \&$ 8 respectively. Main findings are listed below:

- Sugar economic group has liquidity and total asset turnover ratio above overall average, but the profitability of this economic group is below overall average. It means that the economic group is not properly utilizing its liquidity for generation of profits, it needs to convert its cash into profits.

- Textile sector has profitability, efficiency and liquidity below the overall average of economic groups. It means that the textile economic group is not having sufficient liquid assets to convert them into sales and earn profitability. They need to increase their liquidity and use it in efficient projects to increase profitability.

- Electric machinery economic group has liquidity above the overall position but this economic group is unable to convert liquidity in to profitability and efficiency as they are below the overall position. So, they need to efficiently use their liquid assets and convert them into sales and profits.

- Textile sector showed negative growth in Sales despite 27\% growth in Total Assets during the same time period. Similarly, "Sugar" economic group showed $8 \%$ growth in sales despite encouraging growth in Total Assets and Shareholder Equity. "Information, Comm. \& transport services" economic group showed a high negative growth of $95 \%$ which leads to lower ROA. 
Table 7: Summary of the Ratio Analysis

\begin{tabular}{|c|c|c|c|}
\hline Criteria & Measures & Above Overall Sectors & Below Overall Sectors \\
\hline \multirow[t]{2}{*}{ Profitability Ratios } & ROA & $\begin{array}{l}\text { Public, Food, Chemicals, Cement, Motor vehicle, Fuel \& } \\
\text { energy sector and Coke economic group. }\end{array}$ & $\begin{array}{l}\text { Private, Textile, Sugar, Manufacturing, Minerals, Info. Comm, Electric } \\
\text { machinery sector and other Services Sector. }\end{array}$ \\
\hline & NPM & $\begin{array}{l}\text { Public, Food, Chemicals, Cement, Fuel \& energy sector } \\
\text { and Paper sector. }\end{array}$ & $\begin{array}{l}\text { Private, Textile, Sugar, Manufacturing, Mineral, Motor vehicle, Information, } \\
\text { Coke, Electric and Other services sector. }\end{array}$ \\
\hline \multirow[t]{2}{*}{ Efficiency Ratios } & TAT & Public, Sugar, Food, Motor vehicle and Coke sector & $\begin{array}{l}\text { Private, Textile, Chemicals, Manufacturing, Minerals, Cement, Fuel \& energy, } \\
\text { Information, Paper, Electric Machinery Sector and other services sector. }\end{array}$ \\
\hline & IT & $\begin{array}{l}\text { Public, Cement, Fuel \& energy, Information and Coke \& } \\
\text { refined petroleum sector }\end{array}$ & $\begin{array}{l}\text { Private, Textile, Sugar, Food products, Chemicals, Manufacturing, Minerals, } \\
\text { Motor Vehicles, Paper, Electric machinery sector and Other services sector. }\end{array}$ \\
\hline \multirow[t]{2}{*}{ Leverage Ratios } & D/E Ratio & $\begin{array}{l}\text { Public, Sugar, Fuel \& energy sector and Information } \\
\text { Sector. }\end{array}$ & $\begin{array}{l}\text { Private, Textile, Food, Chemicals, Manufacturing, Minerals, Cement, Motor } \\
\text { vehicle, Paper \& products, Coke \& refined petroleum, Electric machinery } \\
\text { sector and Other services sector. }\end{array}$ \\
\hline & D/A Ratio & Public, Sugar sector and Information \& transport sector. & $\begin{array}{l}\text { Private, Textile, Food, Chemicals, Manufacturing, Fuel \& energy, Minerals, } \\
\text { Cement, Motor vehicle, Paper \& products, Coke \& refined petroleum, Paper, } \\
\text { Electric machinery sector and Other services sector. }\end{array}$ \\
\hline \multirow[t]{2}{*}{ Liquidity Ratios } & Current Ratio & $\begin{array}{l}\text { Public, Food, Cement, Motor Vehicle, Fuel \& energy, } \\
\text { Coke \& refined pet., Paper products, Electric machinery } \\
\text { sector and Other services sector }\end{array}$ & $\begin{array}{l}\text { Private, Textile, Sugar, Chemicals, Manufacturing, Minerals sector and } \\
\text { Information and transport sector. }\end{array}$ \\
\hline & Quick Ratio & $\begin{array}{l}\text { Public, Cement, Motor vehicle, Fuel \& energy, Coke \& } \\
\text { refined pet., Paper and products, Electric machinery } \\
\text { sector and Other services sector. }\end{array}$ & $\begin{array}{l}\text { Private, Textile, Sugar, Food products, Chemicals, Manufacturing, Minerals } \\
\text { sector and Information sector. }\end{array}$ \\
\hline
\end{tabular}


Table 8: Growth Analysis

\begin{tabular}{|l|l|l|}
\hline Growth Measures & Above 50\% & Below 50\% \\
\hline Total Assets & $\begin{array}{l}\text { Public, Manufacturing, } \\
\text { Minerals and Fuel \& } \\
\text { energy. }\end{array}$ & $\begin{array}{l}\text { All sector overall, Private, Textile, } \\
\text { Sugar, Food, Chemicals products, } \\
\text { Cement, Motor vehicle, Info. \& } \\
\text { transport services, Coke \& refined pet., } \\
\text { Paper products, Electric machinery and } \\
\text { Other services. }\end{array}$ \\
\hline Current Assets & $\begin{array}{l}\text { Public, Mineral, Fuel \& } \\
\text { energy, Other services. }\end{array}$ & $\begin{array}{l}\text { All sector overall, Private, Textile, } \\
\text { Sugar, Food, Chemicals products, } \\
\text { Manufacturing, Cement, Motor vehicle, } \\
\text { Info. \& transport services, Coke \& } \\
\text { refined pet., Paper products and } \\
\text { Electric machinery. }\end{array}$ \\
\hline $\begin{array}{l}\text { Shareholder } \\
\text { Equity }\end{array}$ & $\begin{array}{l}\text { All sector overall, Private, } \\
\text { Public, Textile, Sugar, } \\
\text { Food, Chemical products, } \\
\text { Manufacturing, Mineral } \\
\text { products, Cement, Motor } \\
\text { vehicle, Fuel \& energy, } \\
\text { Coke and refined pet., } \\
\text { Paper products and Electric } \\
\text { machinery. }\end{array}$ & $\begin{array}{l}\text { Info. \& transport services and other } \\
\text { services activities. }\end{array}$ \\
$\begin{array}{l}\text { Manufacturing, Mineral } \\
\text { product, Cement and Other } \\
\text { services activities. }\end{array}$ & $\begin{array}{l}\text { Textile, Sugar, Food, Chemicals } \\
\text { products, Motor vehicle, Fuel \& } \\
\text { energy, Info. \& transport services, } \\
\text { Coke and refined pet., Paper products } \\
\text { and Electric machinery. }\end{array}$ \\
\hline Sales & $\begin{array}{l}\text { All sector overall, Private, Public, } \\
\text { / }\end{array}$ & \\
\hline
\end{tabular}

\section{Conclusion, Limitations, and Future Research}

The purpose of the study was to have comparative financial analysis of economic groups of Pakistan based on the data of Joint Stock companies listed at Pakistan Stock Exchange. Ratio analysis, growth analysis and trend analysis techniques were used for this purpose.

Results for growth analysis indicate that the growth of public sector and fuel \& energy is more for assets and equity but their sales growth is less. It is recommended that these sectors should use their assets and shareholder equity for increasing their sales and profitability. Ratio analysis results shows that the Private and Textile sectors are performing below the overall position in profitability, efficiency and liquidity ratios. Which is not good for the financial health of these sectors, they need to make efficient use of their assets to convert them in to profits. The sectors such as paper products and electric machinery etc., showing higher liquidity should utilize their liquidity into profitable investment."Textile", "Sugar" and "Information, Comm. \& transport services" sector need more concentration to generate profits.

There are some limitations to this study. First, the study takes in to account the consolidated data for economic sectors only. Therefore, it is difficult to pinpoint which firms with in the economic groups are contributing towards the high performance or otherwise future research can be done to investigate this. Second, more rigorous analysis can be done to investigate the impact of liquidity, efficiency, leverage and profitability etc. on the performance of the 
economic groups by using some regression techniques and ANOVA etc. Third, strategic and management aspects such as strategic orientation of the economic groups and working capital policies etc. can be added to the financial analysis for future research.

\section{References}

Ahrendsen, B.L., Nwoha, O.J., Dixon, B.L., Settlage, D.M., \& Chavez, E.C. (2007). FSA direct loan targeting: successful and financially necessary? Agricultural Finance Review, 67(1), 35-53.

Bashir, Z., \& Akram, M. N. (2013). Empirical Investment of the Factors Affecting Firm's Performance: a Study Based on Food Sector of Pakistan, 1(2), 11-23.

Courtis, (1978). Modeling a financial ratios categoric financial ratio analysis framework. Journal of Business Finance and Accounting. 5(4), 371-386.

Ehrhardt, C, M., \& Brigham, F, E., (2017). Financial management: theory and practices. Boston (MA): Cengage Learning.

Ezzamel, Mar-Molinero, \& Beecher. (1987). The distributional properties of financial ratios. Journal of Business Finance and Accounting. 14(4), 463-481.

Frase, L., \& Ormiston, A. (2004). Understanding Financial Statements. New Jersey: Pearson Prentice Hall.

Gibson, Charles, H. (2014). Financial Reporting and Analysis, University of Toledo, Emeritus.

Horn, J.C., \& Wachowicz, J.M. (2009). Financial Statement Analysis, Fundamentals of Financial Management (13 ${ }^{\text {th }}$ ed., pp. 127-167).

Kirkpatrick., et al. (2007). The Measurement and Determinants of X-inefficiency in Commercial Banks in SubSaharan Africa. European Journal of Finance, 7(2), 625-639.

Lawrence J.G. (1997). Principles of Managerial Finance.114-115.

Leslie R,. (1997). Go with the flow: Using Ratios to analyze cash flow data. The National Public Accountant

Owens \& Epstein. (1995). FW's Growth 100. Financial World .54-55.

Perttunen \& Martikainen. (1990). The functional form of earnings and stock prices: international evidence and implications for the E/P anomaly. Journal of Business Finance and Accounting. 21(3), 395-408.

Ramathan. (2007). Performance of Banks in Countries of the Gulf Cooperation Council., International Journal of Productivity and Performance Management, 56(2), 137-154.

Tahir, T. M. (2012). Company operation performance using DEA and performance matrix: Evidence from Pakistan.

Tamimi. (2010).Factors Influencing Performance of the UAE Islamic and Conventional National Banks. Global Journal of Business Research, 4(2), 1-9. 